\title{
Analisis Tingkat Kesehatan Bank Dengan Metode RGEC: Studi Kasus Bank Milik Pemerintah Terdaftar Di BEI Periode 2014-2018
}

\author{
Sutri Handayani, Henny Mahmudah \\ Fakultas Ekonomi, Universitas Islam Lamongan \\ Email authors: sutrihandayani99@gmail.com/hennyimam@yahoo.co.id
}

\begin{abstract}
ABSTRAK
Penelitian ini bertujuan untuk mengetahui dan menganalisa tingkat kesehatan Bank Milik Pemerintah tahun 2014-2018 ditinjau dari aspek Risk Profile, Good Corporate Governance (GCG), Earnings, Capital, dan RGEC (Risk Profile, GCG, Earnings, dan Capital) secara keseluruhan. Jenis penelitian ini adalah deskriptif kuantitatif dengan subjek penelitian berupa Bank Milik Pemerintah yang terdaftar di Bursa Efek Indonesia tahun 2014-2018. Data diperoleh melalui teknik dokumentasi dan studi pustaka. Teknik analisis data yang digunakan adalah analisis kesehatan bank dengan pendekatan Risiko (Risk-based Bank Rating) dengan cakupan penilaian meliputi faktor-faktor RGEC. Hasil penelitian menunjukkan bahwa selama tahun 2014-2018: (1) Aspek Risk profile Bank Milik Pemerintah menunjukkan NPL bank di bawah 5 persen dan LDR bank berpredikat cukup baik. (2) Aspe Good Corporate Governance menunjukkan bank mendapatkan predikat sangat baik di tahun 2014 dan baik di tahun 2015 - 2018. (3) Aspek Earnings menunjukkan ROA bank lebih dari 1,5 persen dan NIM bank lebih dari 3 persen. (4) Aspek Capital menunjukkan CAR bank sangat sehat dan terpenuhinya kewajiban penyediaan modal minimum sebesar 8 persen. (5) Aspek RGEC secara keseluruhan berturut - turut berada dalam Peringkat Komposit 1 yaitu sangat sehat untuk Bank BNI, BRI, dan Mandiri sedangkan Bank BTN mendapatkan peringkat 2 yaitu sebagai bank yang sehat.Berdasarkan hasil penelitian dapat disimpulkan bahwa Bank Milik Pemerintah untuk Bank BNI, BRI, dan Mandiri merupakan bank yang sangat sehat serta Bank BTN merupakan bank yang sehat berdasarkan analisis laporan keuangan dengan menggunakan metode RGEC.
\end{abstract}

Kata Kunci: Tingkat kesehatan bank, bank milik pemerintah, metode RGEC

\section{PENDAHULUAN}

Kesehatan bank merupakan hasil dari penilaian kualitas atas berbagai aspek yang berpengaruh terhadap kondisi kinerja suatu bank. Pada PBI No. 13/1/PBI/2011 dan SE No. 13/ 24/ DPNP tanggal 25 Oktober 2011 setiap bank diwajibkan melakukan penilainan tingkat kesehatan bank dengan menggunakan pendekatan Risiko (Riskbased bank Rating/RBBR) atau RGEC sebagai indikator baik secara individual maupun secara konsolidasi, dengan cakupan penilaian meliputi faktor-faktor sebagai berikut: profil risiko (risk profile) merupakan penilaian terhadap risiko inheren dan kualitas penerapan manajemen risiko dalam aktivitas operasional bank.

Tujuan dari penelitian ini adalah untuk mengetahui dan menganalisis tingkat kesehatan bank milik pemerintah yang terdaftar pada Bursa Efek Indonesia ditinjau dari faktor risk profile pada tahun 2014-2018; untuk mengetahui dan menganalisis 
tingkat kesehatan bank milik pemerintah yang terdaftar pada Bursa Efek Indonesia ditinjau dari faktor good corporate governance pada tahun 2014-2018; untuk mengetahui dan menganalisis tingkat kesehatan bank milik pemerintah yang terdaftar pada Bursa Efek Indonesia ditinjau dari faktor eraning pada tahun 20142018; untuk mengetahui dan menganalisis tingkat kesehatan bank milik pemerintah yang terdaftar pada Bursa Efek Indonesia ditinjau dari faktor capital pada tahun 2014-2018; dan untuk mengetahui dan menganalisis tingkat kesehatan bank milik pemerintah secara keseluruhan berdasarkan metode RGEC yang terdaftar pada Bursa Efek Indonesia pada tahun 2014-2018.

\section{METODE PENELITIAN}

Jenis penelitian ini adalah penelitian deskriptif kuantitatif yaitu dengan cara menganalisis Laporan Keuangan yang kemudian ditabulasikan untuk kategori perusahaan perbankan tersebut dapat dikatakan sehat atau tidak sehat. Penelitian deskriptif adalah penelitian yang dilakukan untuk mengetahui nilai variabel mandiri, baik satu variabel atau lebih (independen) tanpa membuat perbandingan atau menghubungkan dengan variable yang lain (Sugiyono, 2016: 35).

Jenis data yang digunakan dalam penelitian ini adalah data sekunder. Data sekunder adalah data yang diperoleh dari pihak kedua, misalnya melalui orang lain atau dokumen yang sudah dipublikasikan dan membaca buku-buku serta jurnal yang berhubungan dengan penelitian. Dalam penelitian ini data sekunder diperoleh dari masing-masing website resmi Bank Milik Pemerintah yaitu annual report tahun 2014-2018 dan laporan tahunan yang dipublikasikan di situs resmi Bursa Efek Indonesia (www.idx.co.id) serta sumber-sumber lain yang relevan dengan data yang dibutuhkan.Tingkat kesehatan bank merupakan hasil penilaian dari kondisi bank yang dilakukan terhadap risiko dan kinerja bank untu menjalankan fungsinya dengan baik. Sesuai dengan Peraturan Bank Indonesia No. 13/1PBI/2011 dan SE No. 13/24/DPNP tanggal 25 Oktober 2011.

Tabel 1. Operasional variabel

\begin{tabular}{|c|c|c|c|}
\hline Teori/Konsep & Variabel & Indikator & Skala \\
\hline \multirow{6}{*}{ Tingkat Kesehatan Bank } & \multirow[t]{2}{*}{ Risk Profile } & NPL & $\frac{\text { Kredit Bermasalah }}{\text { Total Kradit }} \times 1009$ \\
\hline & & LDR & $\frac{\text { TotalKredit }}{\text { DanaPihakKetiga }} x 1009$ \\
\hline & GCG & Self Assesment & Hasil Self Assesment \\
\hline & \multirow[t]{2}{*}{ Earning } & $\mathrm{ROA}$ & $\frac{\text { Laba Sebelwm Pajak }}{\text { Rata-Rata Total Aset }} x$ 1008E \\
\hline & & NIM & $\frac{\text { Pendopatan Bumga Bersih }}{\text { Total Aset Produktif }} \times 1009$ \\
\hline & Capital & CAR & $\frac{\text { Modal }}{\text { ATMR }} \times 1009$ \\
\hline
\end{tabular}


Tabel 2. Bobot penetapan peringkat komposit

\begin{tabular}{|c|c|c|}
\hline Bobot & Peringkat Komposit & Keterangan \\
\hline $86-100$ & PK 1 & Sangat Sehat \\
\hline $71-85$ & PK 2 & Sehat \\
\hline $61-70$ & PK 3 & Cukup Sehat \\
\hline $41-60$ & PK 4 & Kurang Sehat \\
\hline$<40$ & PK 5 & Tidak Sehat \\
\hline \multicolumn{3}{|c|}{ Jumlah Nilai Komposit } \\
\hline Peringkat & Total Nilai Komposit & whan $^{x}$ \\
\hline
\end{tabular}

Sumber: Refmasari dan Setiawan (2014) dalam Sandhy (2015)

\section{TEMUAN DAN PEMBAHASAN}

\section{Hasil Penelitian}

Penilaian kesehatan Bank merupakan penilaian terhadap kemampuan Bank dalam menjalankan kegiatan operasional perBankan secara normal dan kemampuan Bank dalam memenuhi kewajibannya. Berdasarkan Peraturan Bank Indonesia No. 13/ 1/ PBI/ 2011 dan SE No. 13/ 24/ DPNP tanggal 25 Oktober 2011 tentang Sistem Penilaian Tingkat Kesehatan Bank Umum, Penilaian kesehatan Bank meliputi faktor-faktor sebagai berikut:

\section{Tingkat Kesehatan Bank ditinjau dari Aspek Risk Profile}

1. NPL (Non Performing Loan)

Diketahui bahwa nilai rata-rata rasio NPL terbaik untuk Bank Milik Pemerintah terjadi pada tahun 2015 dengan nilai sebesar 2,27\% dan mendapat predikat sehat. Nilai rata-rata untuk rasio NPL mengalami tren negatif dimana selalu terjadi peningkatan nilai setiap tahunnya, dan nilai rata-rata tertinggi untuk rasio NPL terjadi pada tahun 2018 sebesar 2,69\%. Ini menandakan bahwa semakin tahun Bank Milik Pemerintah memiliki kualitas kredit yang semakin memburuk.

\section{LDR (Loan to Deposit Ratio)}

Diketahui bahwa nilai rata-rata rasio LDR terbaik untuk Bank Milik Pemerintah terjadi pada tahun 2014 dengan nilai sebesar $86,71 \%$ dengan mendapat predikat sehat dan nilai rata-rata tertinggi terjadi pada tahun 2017 sebesar 96,04\%. Setiap tahunnya rasio LDR memiliki tren yang negatif dalam perkembangannya dimana setiap tahunnya nilai rata-rata LDR semakin tinggi, hal ini menunjukkan bahwa Bank terlalu agresif dalam menyalurkan kredit sehingga dapat meningkatkan eksposur risiko yang dihadapi. 
Tingkat Kesehatan Bank ditinjau dari Aspek GCG

Diketahui bahwa nilai rata - rata GCG mengalami tren yang fluktuatif terlihat dari nilai yang dihasilkan. Pada tahun 2014 rata-rata nilai GCG Bank Milik Pemerintah sebesar 1,37. GCG terbaik pada tahun tersebut dimiliki oleh BNI dengan nilai sebesar 1,30 selanjutnya diikuti oleh BRI dengan nilai 1,31 kemudian BTN 1,35 dan Mandiri 1,50. Pada tahun 2015 rata-rata nilai GCG Bank Milik Pemerintah sebesar 2,06. GCG terbaik pada tahun tersebut diperoleh BRI dengan nilai 1,22 kemudian diikuti oleh BNI dan Mandiri dengan nilai 2 dan BTN memiliki nilai 3. Selanjutnya pada tahun 2016 rata-rata nilai GCG Bank Milik Pemerintah sebesar 1,78. GCG terbaik pada tahun tersebut dimiliki oleh BRI dengan nilai 1,12 diikuti oleh BNI, BTN dan Mandiri dengan memperoleh nilai sama yaitu 2. Pada tahun 2017 rata-rata nilai GCG Bank Milik Pemerintah sebesar 1,54. GCG terbaik pada tahun tersebut diperoleh Mandiri dengan nilai 1 kemudian diikuti oleh BRI dengan nilai 1,15, terakhir BNI dan BTN dengan nilai yang sama yaitu 2. Pada tahun 2018 rata-rata nilai GCG Bank Milik Pemerintah sebesar 1,75. GCG terbaik pada tahun tersebut diperoleh Mandiri dengan nilai 1 kemudian diikuti oleh BNI, BRI dan BTN dengan nilai yang sama yaitu 2 .

\section{Tingkat Kesehatan Bank ditinjau dari Aspek Earning}

Rasio keuangan yang digunakan dalam menilai tingkat kesehatan Bank Milik Pemerintah ditinjau dari aspek earning pada penelitian ini dengan menggunakan 2 rasio yaitu rasio ROA dan rasio NIM. Rasio ini digunakan untuk mengukur tingkat efisiensi usaha, profitabilitas yang dicapai Bank, serta kemampuan Bank dalam meningkatkan keuntungan dalam suatu periode.

\section{ROA (Return on Asset)}

Diketahui bahwa nilai rata-rata rasio ROA terbaik untuk Bank Milik Pemerintah terjadi pada tahun 2015 dengan nilai rata-rata sebesar 3,29\% dengan mendapat predikat sehat dan nilai rata-rata terendah terjadi pada tahun 2018 sebesar 2,45\%. Setiap tahunnya rasio ROA memiliki tren atau kecenderungan yang negatif setelah tahun 2015 dalam perkembangannya, dimana setiap tahunnya nilai rata-rata ROA semakin menurun atau kecil. Hal ini mengindikasikan bahwa kurangnya kemampuan manajemen Bank dalam hal mengelola aktiva untuk meningkatkan pendapatan dan atau menekan biaya.

\section{NIM (Net Interest Margin)}

Diketahui bahwa nilai rata-rata rasio NIM memilik tren yang fluktuatif untuk setiap tahunnya. Terlihat dari rasio NIM pada tahun 2015 yang meningkat dari 5,71\% menjadi 6,03\%. Kemudian menurun pada tahun 2016 menjadi 5,64\% dan kembali meningkat sebesar 6,08\% pada tahun 2017 yang terus meningkat pada tahun 2018 menjadi 6,13\%. Rata - rata nilai rasio NIM terendah terjadi pada tahun 2016 sebesar 5,64\% dan terbaik pada tahun 2018 sebesar 6,13\%. Dimana pada tahun 2018 rasio NIM terbaik diperoleh oleh ban BRI sebesar 8,58\% diikuti 
Bank BNI sebesar 5,66\%, Bank Mandiri sebesar 5,61\%, dan terakhir Bank BTN sebesar $4,66 \%$.

\section{Tingkat Kesehatan Bank ditinjau dari Aspek Capital}

Diketahui bahwa nilai rata - rata rasio CAR mengalami tren atau kecenderungan yang positif dimana setiap tahunnya permodalan yang dimiliki oleh Bank Milik Pemerintah semakin membaik. Namun pada tahun 2015 nilai rasio CAR sedikit menurun menjadi $15,66 \%$ dari nilai CAR sebelumnya sebesar $16,70 \%$. Nilai rasio CAR terbaik terjadi pada tahun 2018 sebesar 20,99 persen. Pada tahun 2018 rasio CAR terbaik diliki oleh Bank BRI sebesar 22,91\% kemudian Bank Mandiri sebesar 21,36\%, selanjutnya BTN sebesar 20,34\%, dan BNI sebesar 19,36\%. Bank BRI adalah Bank yang paling baik diantara keempat Bank Milik Pemerintah dalam kecukupan permodalan yang dimiliki selama lima tahun terakhir..

\section{Tingkat Kesehatan Bank ditinjau dari Aspek RGEC}

Hasil penilaian tingkat kesehatan Bank Milik Pemerintah berdasarkan Metode RGEC (Risk profile, Good Corporate Governance, earnings, dan Capital) selama tahun 2014-2018 dapat disajikan dalam tabel sebagai berikut:

Tabel 1. Peringkat Komposit Bank BNI Berdasarkan Metode RGEC 2014-2018

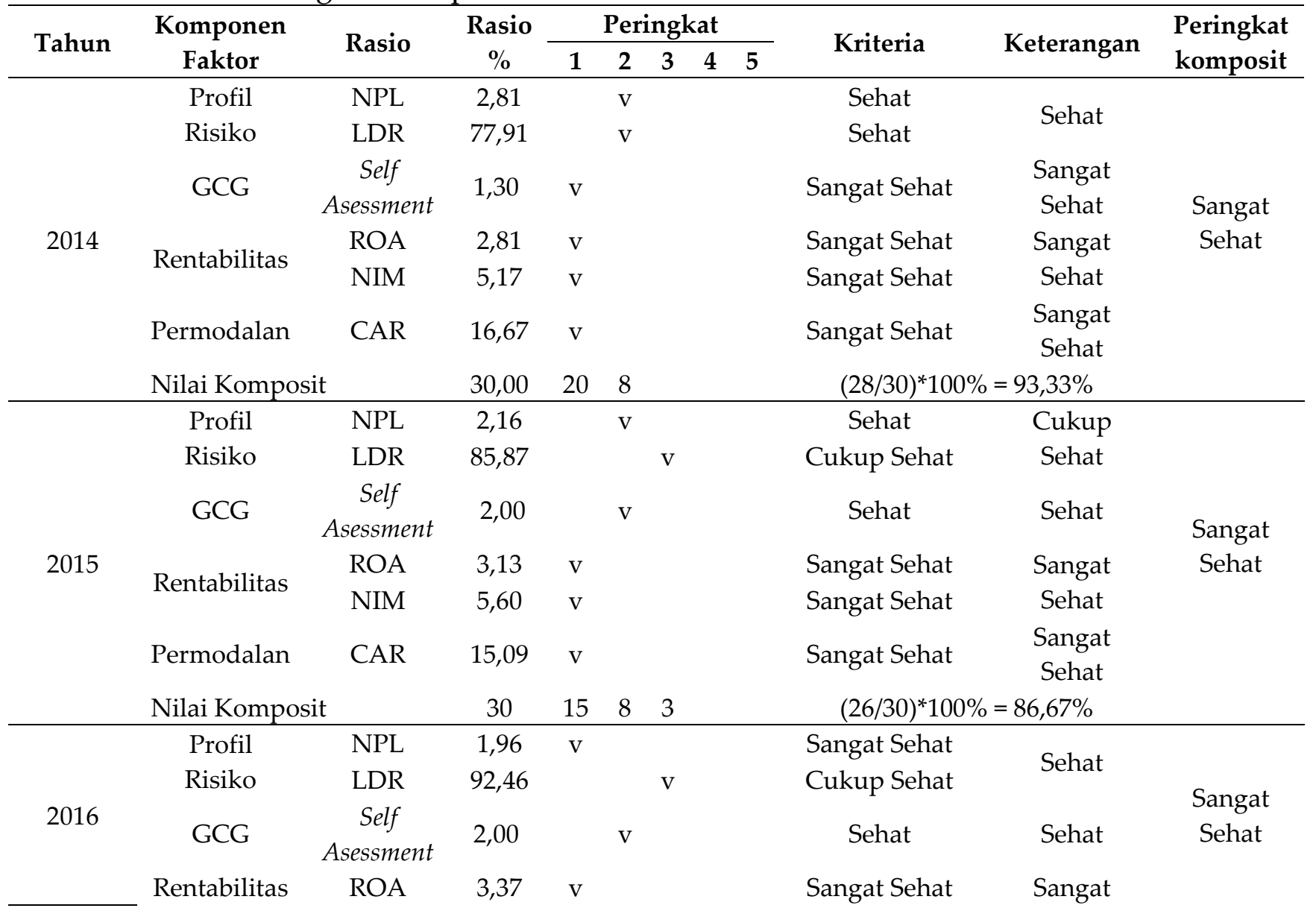




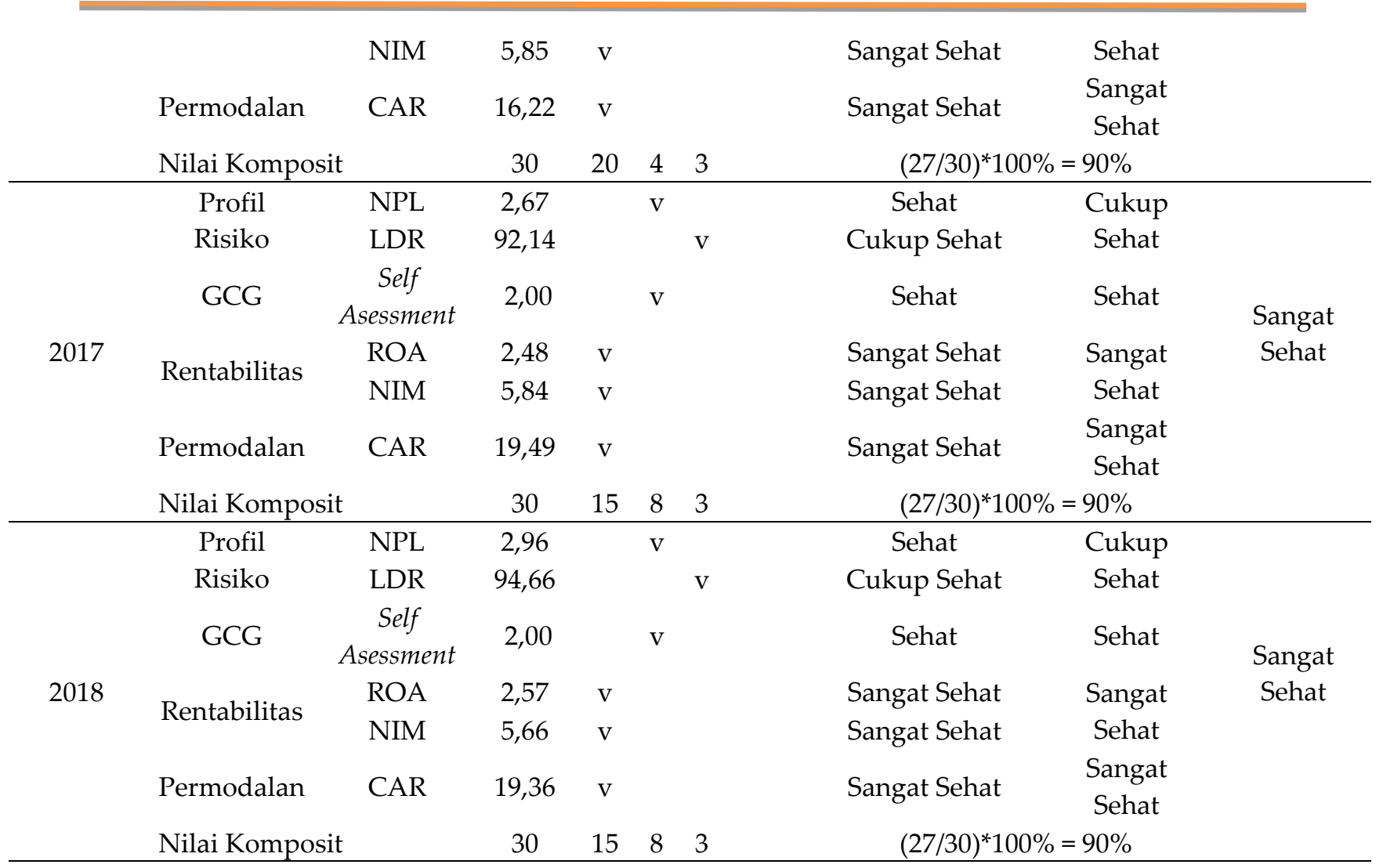

Sumber : Data sekunder yang diolah oleh peneliti, 2018

Tabel 2. Peringkat Komposit Bank BRI Berdasarkan Metode RGEC 2014-2018

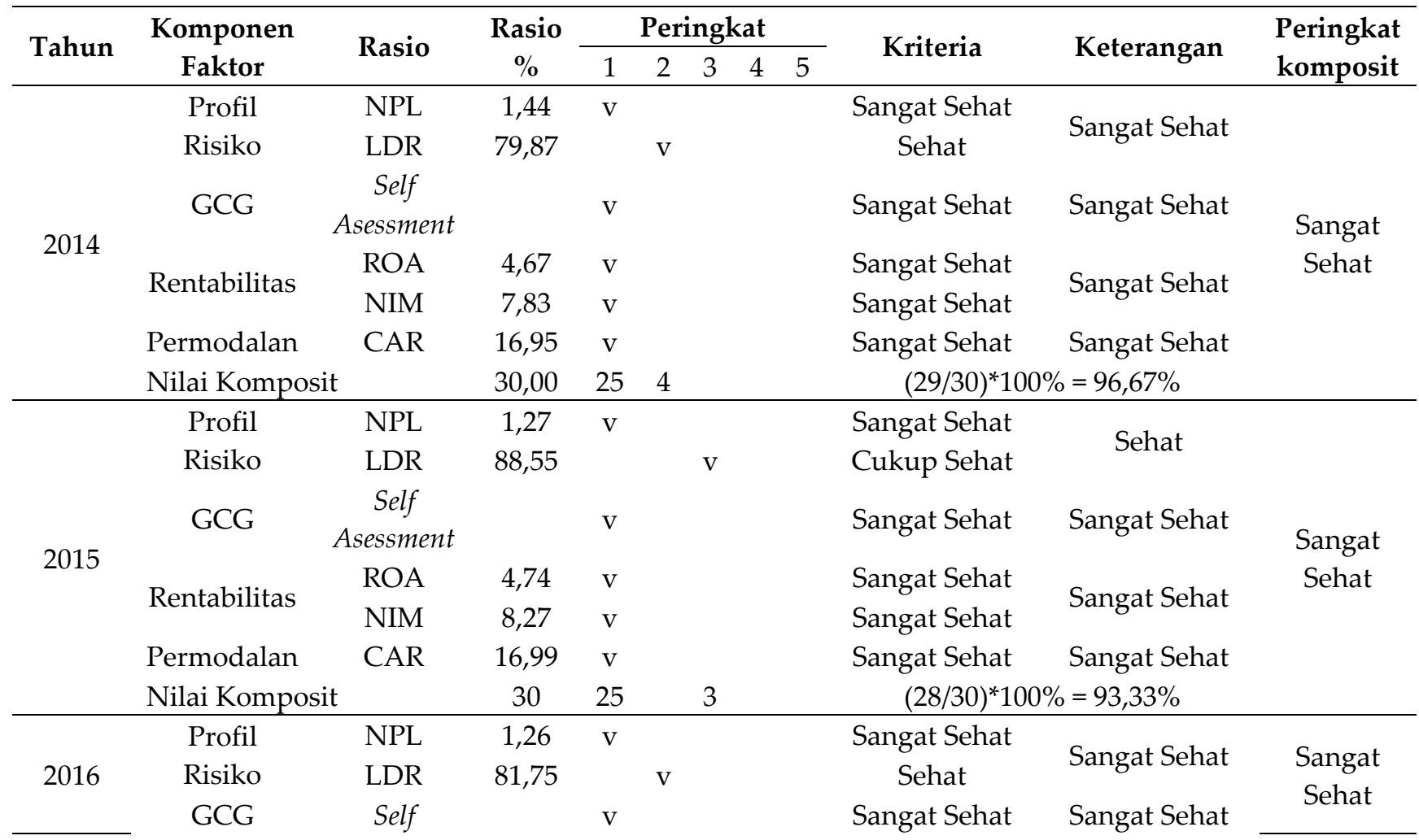




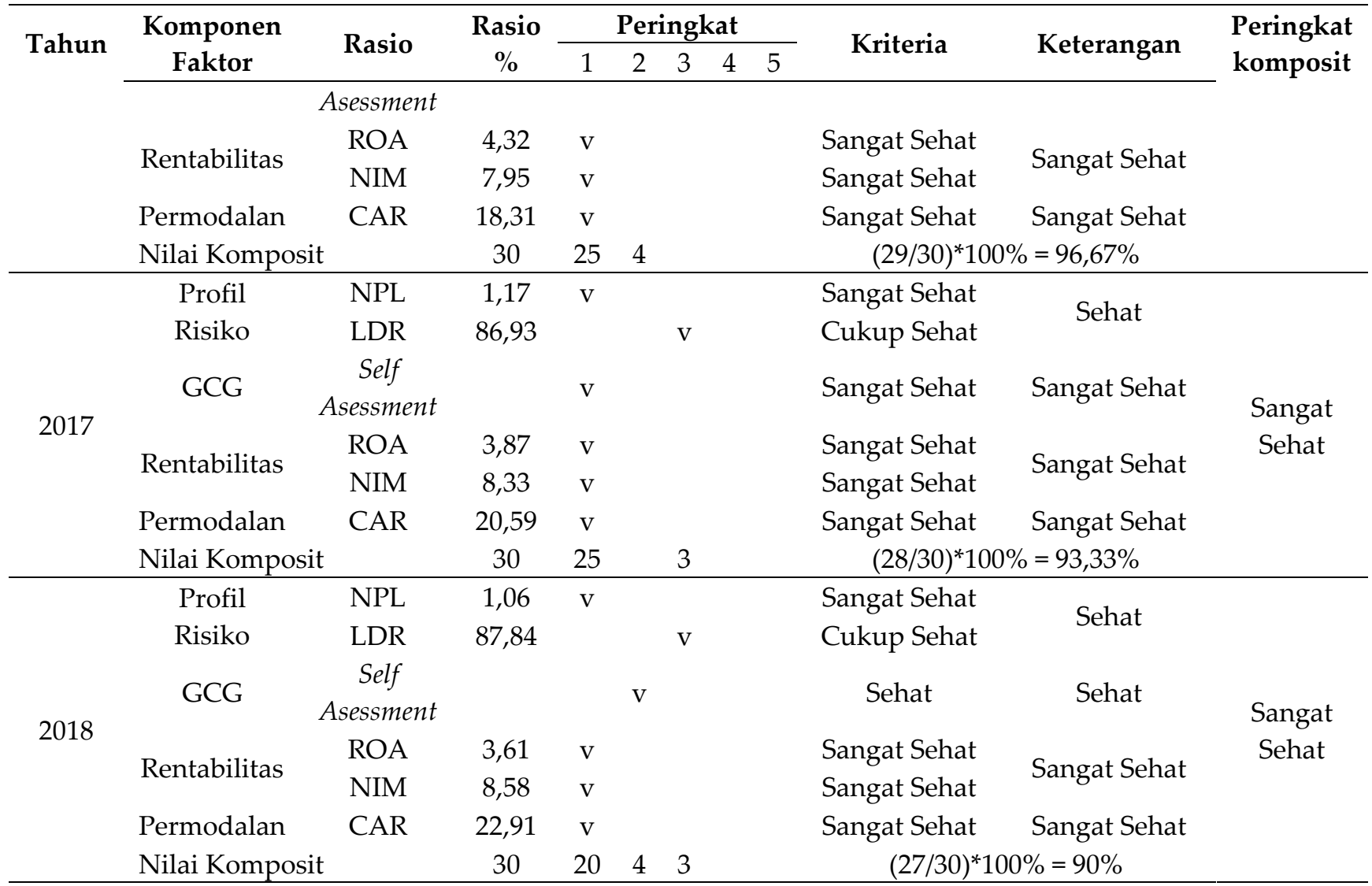

Sumber : Data sekunder yang diolah oleh peneliti, 2018

Tabel 3. Peringkat Komposit Bank BTN Berdasarkan Metode RGEC 2014-2018

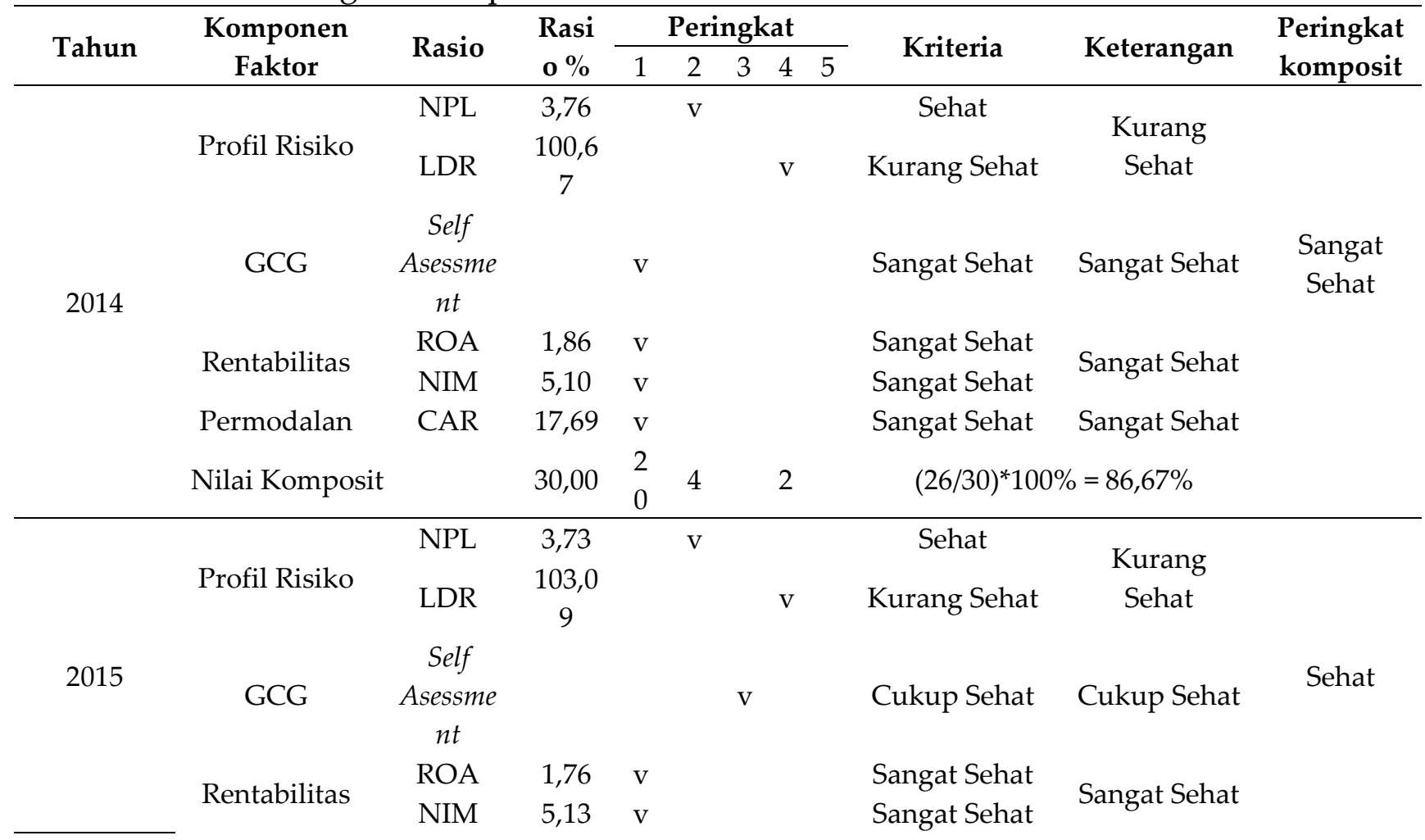




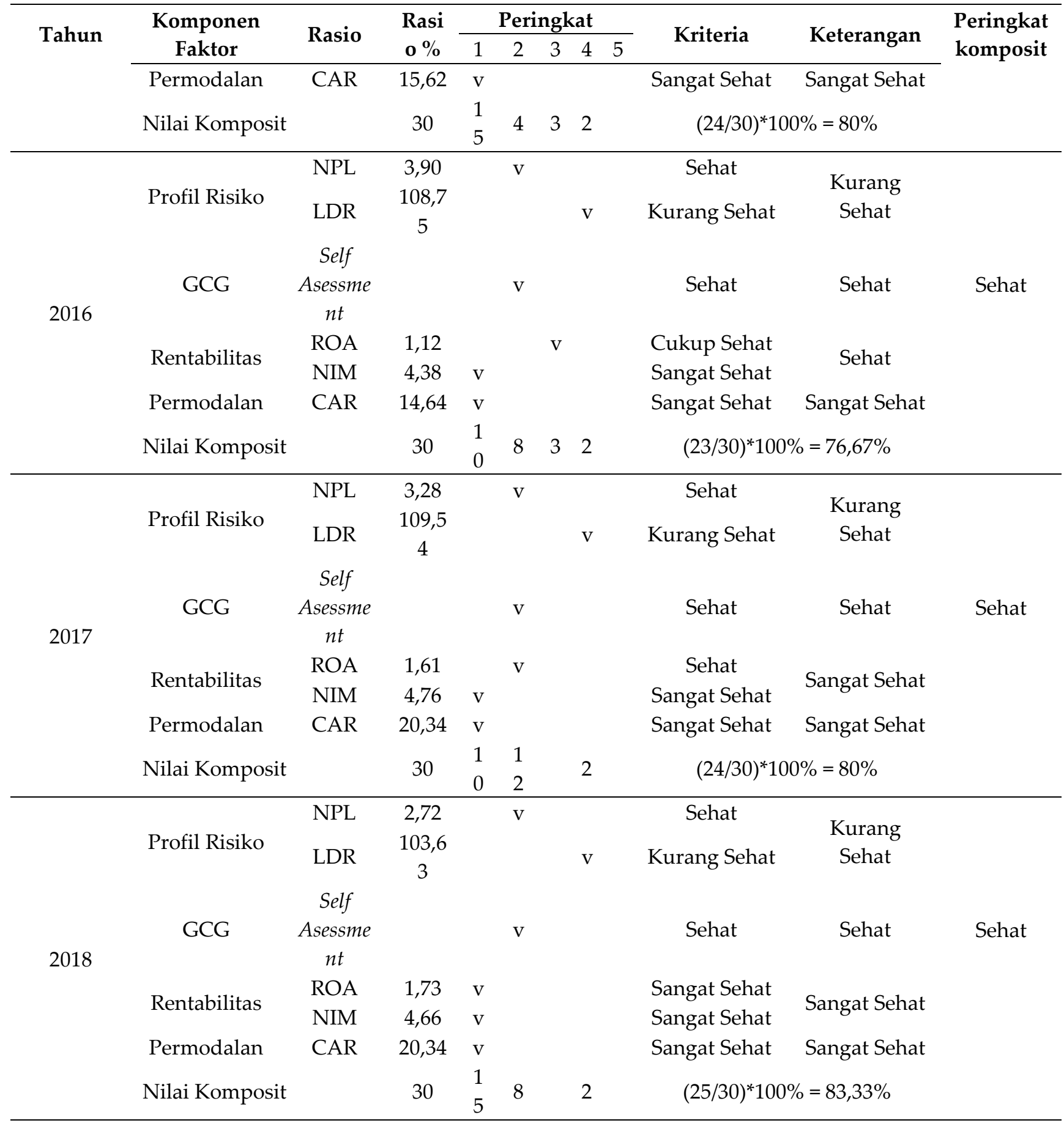

Sumber : Data sekunder yang diolah oleh peneliti, 2018 
Tabel 6. Peringkat Komposit Bank Mandiri Berdasarkan Metode RGEC 2014-2018

\begin{tabular}{|c|c|c|c|c|c|c|c|c|c|c|}
\hline \multirow{2}{*}{ Tahun } & \multirow{2}{*}{$\begin{array}{c}\text { Komponen } \\
\text { Faktor }\end{array}$} & \multirow{2}{*}{ Rasio } & \multirow{2}{*}{$\begin{array}{c}\text { Rasio } \\
\%\end{array}$} & \multicolumn{4}{|c|}{ Peringkat } & \multirow{2}{*}{ Kriteria } & \multirow{2}{*}{ Keterangan } & \multirow{2}{*}{$\begin{array}{l}\text { Peringkat } \\
\text { komposit }\end{array}$} \\
\hline & & & & 1 & 2 & 34 & 5 & & & \\
\hline \multirow{7}{*}{2014} & Profil & NPL & 1,88 & $\mathrm{v}$ & & & & Sangat Sehat & Sobot & \multirow{7}{*}{$\begin{array}{l}\text { Sangat } \\
\text { Sehat }\end{array}$} \\
\hline & Risiko & LDR & 88,39 & & & $\mathrm{v}$ & & Cukup Sehat & Senat & \\
\hline & $\begin{array}{c}\text { Good } \\
\text { Corporate } \\
\text { Governance }\end{array}$ & $\begin{array}{c}\text { Self } \\
\text { Asessment }\end{array}$ & & $\mathrm{v}$ & & & & Sangat Sehat & Sangat Sehat & \\
\hline & \multirow{2}{*}{ Rentabilitas } & ROA & 3,45 & $\mathrm{v}$ & & & & Sangat Sehat & \multirow{2}{*}{ Sangat Sehat } & \\
\hline & & NIM & 4,74 & $\mathrm{v}$ & & & & Sangat Sehat & & \\
\hline & Permodalan & CAR & 15,48 & $\mathrm{v}$ & & & & Sangat Sehat & Sangat Sehat & \\
\hline & Nilai Komposit & & 30,00 & 25 & & 3 & & $(28 / 30)^{*} 100$ & $=93,33 \%$ & \\
\hline \multirow{7}{*}{2015} & Profil & NPL & 1,91 & $\mathrm{v}$ & & & & Sangat Sehat & Sebat t & \multirow{7}{*}{$\begin{array}{l}\text { Sangat } \\
\text { Sehat }\end{array}$} \\
\hline & Risiko & LDR & 93,46 & & & $\mathrm{v}$ & & Cukup Sehat & senat & \\
\hline & $\begin{array}{c}\text { Good } \\
\text { Corporate } \\
\text { Governance }\end{array}$ & $\begin{array}{c}\text { Self } \\
\text { Asessment }\end{array}$ & & $\mathrm{v}$ & & & & Sangat Sehat & Sangat Sehat & \\
\hline & \multirow{2}{*}{ Rentabilitas } & ROA & 3,52 & $\mathrm{v}$ & & & & Sangat Sehat & \multirow{2}{*}{ Sangat Sehat } & \\
\hline & & NIM & 5,01 & $\mathrm{v}$ & & & & Sangat Sehat & & \\
\hline & Permodalan & CAR & 14,93 & $\mathrm{v}$ & & & & Sangat Sehat & Sangat Sehat & \\
\hline & Nilai Komposit & & 30 & 25 & & 3 & & $(28 / 30)^{*} 100$ & $=93,33 \%$ & \\
\hline \multirow{7}{*}{2016} & Profil & NPL & 2,16 & & $\mathrm{v}$ & & & Sehat & Cukup Sehat & \multirow{7}{*}{$\begin{array}{l}\text { Sangat } \\
\text { Sehat }\end{array}$} \\
\hline & Risiko & LDR & 90,73 & & & $\mathrm{v}$ & & Cukup Sehat & Cukup seriat & \\
\hline & $\begin{array}{c}\text { Good } \\
\text { Corporate } \\
\text { Governance }\end{array}$ & $\begin{array}{c}\text { Self } \\
\text { Asessment }\end{array}$ & & $\mathrm{v}$ & & & & Sangat Sehat & Sangat Sehat & \\
\hline & \multirow{2}{*}{ Rentabilitas } & $\mathrm{ROA}$ & 3,28 & $\mathrm{v}$ & & & & Sangat Sehat & \multirow{2}{*}{ Sangat Sehat } & \\
\hline & & NIM & 5,12 & $\mathrm{v}$ & & & & Sangat Sehat & & \\
\hline & Permodalan & CAR & 16,60 & $\mathrm{v}$ & & & & Sangat Sehat & Sangat Sehat & \\
\hline & Nilai Komposit & & 30 & 20 & 4 & 3 & & $(27 / 30)^{*} 10$ & $\%=90 \%$ & \\
\hline \multirow{7}{*}{2017} & Profil & NPL & 2,62 & & $\mathrm{v}$ & & & Sehat & Colkun Sehat & \multirow{7}{*}{$\begin{array}{l}\text { Sangat } \\
\text { Sehat }\end{array}$} \\
\hline & Risiko & LDR & 95,55 & & & $\mathrm{v}$ & & Cukup Sehat & Cukup sental & \\
\hline & $\begin{array}{c}\text { Good } \\
\text { Corporate } \\
\text { Governance }\end{array}$ & $\begin{array}{c}\text { Self } \\
\text { Asessment }\end{array}$ & & $\mathrm{v}$ & & & & Sangat Sehat & Sangat Sehat & \\
\hline & \multirow{2}{*}{ Rentabilitas } & $\mathrm{ROA}$ & 2,40 & $\mathrm{v}$ & & & & Sangat Sehat & \multirow{2}{*}{ Sangat Sehat } & \\
\hline & & NIM & 5,40 & $\mathrm{v}$ & & & & Sangat Sehat & & \\
\hline & Permodalan & CAR & 18,60 & $\mathrm{v}$ & & & & Sangat Sehat & Sangat Sehat & \\
\hline & Nilai Komposit & & 30 & 20 & 4 & 3 & & $(27 / 30)^{*} 10$ & $\%=90 \%$ & \\
\hline \multirow{7}{*}{2018} & Profil & NPL & 4,03 & & $\mathrm{v}$ & & & Sehat & Sulkun Sehat & \\
\hline & Risiko & LDR & 93,81 & & & $\mathrm{v}$ & & Cukup Sehat & Cunup sental & \\
\hline & $\begin{array}{c}\text { Good } \\
\text { Corporate } \\
\text { Governance }\end{array}$ & $\begin{array}{c}\text { Self } \\
\text { Asessment }\end{array}$ & & $\mathrm{v}$ & & & & Sangat Sehat & Sangat Sehat & Sangat \\
\hline & Rontabilitac & $\mathrm{ROA}$ & 1,91 & $\mathrm{v}$ & & & & Sangat Sehat & Sangat Sohat & Sehat \\
\hline & Kentabilitas & NIM & 5,61 & $\mathrm{v}$ & & & & Sangat Sehat & Sangat senat & \\
\hline & Permodalan & CAR & 21,36 & $\mathrm{v}$ & & & & Sangat Sehat & Sangat Sehat & \\
\hline & Nilai Komposit & & 30 & 20 & 4 & 3 & & $(27 / 30)^{*} 10$ & $\%=90 \%$ & \\
\hline
\end{tabular}




\section{PEMBAHASAN}

\section{Tingkat Kesehatan Bank Milik Pemerintah Ditinjau Dari Risk Profile}

1. PT. Bank Negara Indonesia, Tbk

a. NPL (Non Performing Loan)

Nilai NPL Bank BNI selama tahun 2014-2018 berturut - turut adalah 2,81 persen 2,16 persen 1,96 persen 2,67 persen dan 2,96 persen. Nilai NPL tersebut menunjukan perkembangan yang fluktuatif namun masih menunjukkan kualitas kredit yang masih berada pada kondisi yang sangat sehat dan sehat.

\section{b. LDR (Loan to Deposit Ratio)}

Nilai LDR Bank BNI selama tahun 2014-2018 berturut - turut adalah 77,91 persen 85,87 persen 92,46 persen 92,14 persen dan 94,66 persen. Nilai LDR tersebut menunjukan tren perkembangan yang selalu meningkat tiap tahunnya. Selama tahun 2014-2018 Bank BNI berada dalam peringkat cukup sehat karena nilai LDR kurang dari 100 persen sesuai Surat Edaran Bank Indonesia No.13/ 24/ DPNP.

\section{PT Bank Rakyat Indonesia, Tbk}

\section{a. NPL (Non Performing Loan)}

Nilai NPL Bank BRI selama tahun 2014-2018 berturut - turut adalah 1,44 persen 1,27 persen 1,26 persen 1,17 persen dan 1,06 persen. Nilai NPL menunjukkan perkembangan atau tren positif dimana nilai NPL yang semakin kecil dari tahun sebelumnya. Nilai NPL yang semakin kecil menunjukkan bahwa semakin menurunnya jumlah kredit bermasalah dari total kredit yang diberikan, yang berarti Bank BRI telah berhasil mengelola kualitas pinjaman yang diberikan dengan lebih baik dalam menyeleksi calon peminjam sehingga jumlah kredit yang tergolong kurang lancar, diragukan dan macet pun berkurang.

b. LDR (Loan to Deposit Ratio)

Nilai LDR Bank BRI selama tahun 2014-2018 berturut - turut adalah 79,87 persen 88,55 persen 81,75 persen 86,93 persen dan 87,84 persen. Nilai LDR tersebut menunjukan tren perkembangan yang negatif. Pada tahun 2015, 2017, dan 2018 nilai LDR meningkat satu level dan mendapat peringkat cukup sehat karena nilai LDR kurang dari 100 persen sesuai Surat Edaran Bank Indonesia No.13/ 24/ DPNP. Sehingga menunjukkan bahwa selama periode tersebut Bank BRI memiliki kemampuan yang cukup baik dalam memenuhi kewajiban jangka pendeknya saat ditagih deposan dengan mengandalkan kredit yang diberikan sebagai sumber likuiditasnya. 


\section{PT. Bank Tabungan Negara, Tbk}

a. NPL (Non Performing Loan)

Nilai NPL Bank BTN selama tahun 2014-2018 berturut - turut adalah 3,76 persen 3,73 persen 3,90 persen 3,28 persen dan 2,72 persen. Nilai NPL tersebut menunjukkan tren perkembangan yang positif, dimana nilai rasio NPL yang dihasilkan semakin kecil yang menandakan adanya penurunan pada kredit bermasalah.

b. LDR (Loan to Deposit Ratio)

Nilai LDR Bank BTN selama tahun 2014-2018 berturut - turut adalah 100,67 persen 103,09 persen 108,75 persen 109,32 persen dan 103,63 persen.

4. PT. Bank Mandiri, Tbk

a. NPL (Non Performing Loan)

Nilai NPL Bank Mandiri selama tahun 2014-2018 berturut - turut adalah 1,88 persen 1,91 persen 2,16 persen 2,62 persen dan 4,03 persen. Nilai NPL memiliki perkembangan atau tren negatif dimana nilai NPL yang semakin besar dari tahun - tahun sebelumnya. Nilai NPL yang semakin besar ini menunjukkan bahwa semakin meningkatnya jumlah kredit bermasalah dari total kredit yang diberikan, yang berarti kinerja Bank Mandiri dalam mengelola kualitas pinjaman yang diberikan semakin menurun dalam menyeleksi calon pinjaman sehingga jumlah kredit yang tergolong kurang lancar, diragukan dan macet pun bertambah.

b. LDR (Loan to Deposit Ratio)

Nilai LDR Bank Mandiri selama tahun 2014-2018 berturut - turut adalah 88,39 persen 93,46 persen 90,73 persen 95,55 persen dan 93,81 persen. Nilai LDR tersebut menunjukan tren perkembangan yang fluktuatif. Pada tahun 2015 dan 2017 nilai LDR meningkat, hal ini disebabkan karena pertumbuhan terhadap kredit sebagai aset yang lebih tingi daripada pertumbuhan simpanan sebagai sumber pendanaan Bank. Pada tahun 2016 dan 2018 terjadi sedikit penurunan nilai pada rasio LDR yang dihasilkan, hal ini menandakan bahwa Bank Mandiri mulai berhati - hati dalam menyalurkan kredit yang diberikan terlihat dari pertumbuhan jumlah kredit sebagai aset yang lebih rendah dari pertumbuhan simpanan sebagai sumber pendanaannya.

\section{Tingkat Kesehatan Bank Milik Pemerintah Ditinjau Dari GCG}

\section{PT. Bank Negara Indonesia, Tbk}

Tingkat kesehatan Bank ditinjau dari Good Corporate Governance berdasarkan hasil self assesment pada Bank BNI tahun 2014 memperoleh nilai 1,30 dengan kriteria sangat sehat sehingga menunjukkan bahwa kualitas manajemen Bank BNI atas 
pelaksanaan prinsip GCG berjalan dengan sangat baik. Sedangkan pada tahun 2015 - 2018 Bank BNI memperoleh nilai yang sama yaitu 2 dengan kriteria sehat.

\section{PT. Bank Rakyat Indonesia, Tbk}

Tingkat kesehatan Bank ditinjau dari Good Corporate Governance berdasarkan hasil self assesment pada Bank BRI pada tahun 2014-2018 berturut turut adalah 1,31 persen 1,27 persen 1,12 persen 1,15 persen 2,00 persen. Pada tahun 2014 - 2017 Bank BRI mendapatkan peringkat sama yaitu sangat sehat atau pada nilai komposit 1 , hal ini menunjukkan bahwa kualitas manajemen Bank BRI atas pelaksanaan prinsip GCG berjalan dengan sangat baik. Sedangkan pada tahun 2018 Bank BRI memperoleh nilai atau komposit 2 dengan kriteria sehat. Meskipun terjadi penurunan satu level dari tahun sebelumnya namun kriteria sehat tersebut menunjukkan bahwa kualitas manajemen Bank BRI atas pelaksanaan GCG telah berjalan dengan baik, sehingga tahun 2018 tersebut Bank BRI tergolong Bank yang terpercaya.

\section{PT. Bank Tabungan Negara, Tbk}

Tingkat kesehatan Bank ditinjau dari Good Corporate Governance berdasarkan hasil self assesment pada Bank BTN tahun 2014 memperoleh nilai 1 dengan kriteria sangat sehat sehingga menunjukkan bahwa kualitas manajemen Bank BTN atas pelaksanaan prinsip GCG berjalan dengan sangat sehat. Sedangkan pada tahun 2015 Bank BTN memperoleh nilai 3 dengan kriteria cukup sehat sehingga menunjukkan bahwa kualitas manajemen Bank BTN atas pelaksanaan prinsip GCG berjalan dengan cukup baik. Pada tahun 2016 - 2018 Bank BTN memperoleh nilai yang sama yaitu 2 dengan kriteria sehat sehingga menunjukkan bahwa kualitas manajemen Bank BTN atas pelaksanaan prinsip GCG berjalan dengan baik.

\section{PT. Bank Mandiri, Tbk}

Tingkat kesehatan Bank ditinjau dari Good Corporate Governance pada tahun 20142018 Bank Mandiri memperoleh nilai 1,50 di tahun 2014 dan nilai 1 pada tahun tahun selanjutnya dengan kriteria yang sama yaitu sangat sehat. Meskipun ditahun 2014 nilai atas GCG meningkat tetapi masih dalam predikat yang sama yaitu sangat sehat sehingga menunjukkan bahwa kualitas manajemen Bank Mandiri atas pelaksanaan prinsip GCG berjalan dengan sangat sehat dan tergolong sebagai Bank yang terpercaya.

\section{Tingkat Kesehatan Bank Milik Pemerintah Ditinjau Dari Earnings}

\section{PT. Bank Negara Indonesia, Tbk}

\section{a. ROA (Return on Asset)}

Nilai ROA Bank BNI selama tahun 2014-2018 berturut - turut adalah 2,81 persen 3,13 persen 3,37 persen 2,48 persen dan 2,57 persen. Nilai NPL tersebut menunjukan tren positif, dimana perkembangan tiap tahunnya selalu mengalami peningkatan. Peningkatan yang terjadi seiring dengan menurunnya rasio kredit bermasalah (NPL) dan meningkatnya rasio likuiditas (LDR) yang berarti juga meningktnya penyaluran kredit. 


\section{b. NIM (Net Interest Margin)}

Nilai NIM Bank BNI selama tahun 2014-2018 berturut - turut adalah 5,17 persen 5,60 persen 5,85 persen 5,84 persen dan 5,66 persen. Pada tahun 2014 - 2017 nilai rasio NIM mengalami sedikit peningkatan hal ini menunjukkan bahwa pendapatan bunga bersih Bank membaik.

\section{PT. Bank Rakyat Indonesia, Tbk}

\section{a. ROA (Return on Asset)}

Nilai ROA Bank BRI selama tahun 2014-2018 berturut - turut adalah 4,67 persen 4,74 persen 4,32 persen 3,87 persen dan 3,61 persen. Nilai rasio ROA memiliki tren perkembangan yang negatif dimana terjadi penurunan nilai dalam tiap tahunnya. Pada tahun 2016 - 2018 rasio ROA mengalami penurunan.

\section{b. NIM (Net Interest Margin)}

Nilai NIM Bank BRI selama tahun 2014-2018 berturut - turut adalah 7,83 persen 8,27 persen 7,95 persen 8,33 persen dan 8,58 persen. Secara umum setiap tahunnya rasio NIM mengalami tren yang positif, dimana terjadi peningkatan pada rasio NIM hal ini menunjukkan bahwa pendapatan bunga bersih Bank semakin membaik.

\section{PT. Bank Tabungan Negara, Tbk}

\section{a. ROA (Return on Asset)}

Nilai ROA Bank BTN selama tahun 2014-2018 berturut - turut adalah 1,86 persen 1,76 persen 1,12 persen 1,61 persen dan 1,73 persen. Peningkatan yang terjadi di tahun 2017 dan 2018 menunjukkan bahwa kemampuan Bank BTN dalam memperoleh laba dengan mengandalkan asetnya telah berjalan dengan sangat baik.

b. NIM (Net Interest Margin)

Nilai NIM Bank BTN selama tahun 2014-2018 berturut - turut adalah 5,10 persen 5,13 persen 4,38 persen 4,76 persen dan 4,66 persen. Pada tahun 2015 dan 2017 terjadi peningkatan pada rasio NIM hal ini menunjukkan bahwa pendapatan bunga bersih Bank membaik. Namun pada tahun 2016 dan 2018 mengalami penurunan nilai rasio NIM.

\section{PT. Bank Mandiri, Tbk}

\section{a. ROA (Return on Asset)}

Nilai ROA Bank Mandiri selama tahun 2014-2018 berturut - turut adalah 3,45 persen 3,52 persen 3,28 persen 2,40 persen dan 1,91 persen. Terjadi peningkatan di tahun 2015, peningkatan yang terjadi seiring dengan meningkatnya rasio likuiditas (LDR) yang berarti juga meningkatnya penyaluran kredit meskipun terjadi sedikit peningkatan pada rasio kredit bermasalah (NPL) sebesar 0,03 persen tetapi dibandingkan dengan pertumbuhan kredit sebesar 5,06 persen jauh lebih besar. Peningkatan ini 
menunjukkan bahwa kemampuan Bank Mandiri dalam memperoleh laba dengan mengandalkan asetnya semakin membaik.

b. NIM (Net Interest Margin)

Nilai NIM Bank Mandiri selama tahun 2014-2018 berturut - turut adalah 4,74 persen 5,01 persen 5,12 persen 5,40 persen dan 5,61 persen. Setiap tahunnya rasio NIM mengalami tren yang positif, dimana terjadi peningkatan pada rasio NIM hal ini menunjukkan bahwa pendapatan bunga bersih Bank Mandiri semakin membaik. Pertumbuhan pendapatan bunga bersih tertinggi terjadi pada tahun 2015 yaitu sebesar 0,28 persen.

\section{Tingkat Kesehatan Bank Milik Pemerintah Ditinjau Dari Capital}

\section{PT. Bank Negara Indonesia, Tbk}

Tingkat kesehatan Bank ditinjau dari aspek Capital dengan mengitung Capital Adequacy Ratio (CAR) pada Bank BNI tahun 2014-2018 memiliki nilai CAR masingmasing adalah 16,67 persen 15,09 persen 16,22 persen 19,49 persen dan 19,36 persen dengan kriteria yang sama yaitu sangat sehat.

\section{PT. Bank Rakyat Indonesia, Tbk}

Tingkat kesehatan Bank ditinjau dari aspek Capital dengan mengitung Capital Adequacy Ratio (CAR) pada Bank BRI tahun 2014-2018 memiliki nilai CAR masingmasing adalah 16,95 persen 16,99 persen 18,31 persen 20,59 persen dan 22,91 persen dengan kriteria yang sama yaitu sangat sehat.

\section{PT. Bank Tabungan Negara, Tbk}

Tingkat kesehatan Bank ditinjau dari aspek Capital dengan menghitung Capital Adequacy Ratio (CAR) pada Bank BTN tahun 2014-2018 memiliki nilai CAR masingmasing adalah 17,69 persen 15,62 persen 14,64 persen 16,97 persen dan 20,34 persen dengan kriteria yang sama yaitu sangat sehat.

\section{PT. Bank Mandiri, Tbk}

Tingkat kesehatan Bank ditinjau dari aspek Capital dengan mengitung Capital Adequacy Ratio (CAR) pada Bank Mandiri tahun 2014-2018 memiliki nilai CAR masing-masing adalah 15,48 persen 14,93 persen 16,60 persen 18,60 persen dan 21,36 persen dengan kriteria yang sama yaitu sangat sehat.

\section{Tingkat Kesehatan Bank Milik Pemerintah Ditinjau Dari RGEC}

\section{PT. Bank Negara Indonesia, Tbk}

Penilaian tingkat kesehatan Bank BNI dengan menggunakan metode RGEC yaitu dengan melihat aspek Risk Profile, Good Corporate Governance, Earnings dan Capital selama tahun 2014-2018 berada pada peringkat komposit 1 (PK-1) dengan kriteria sangat sehat. Dengan nilai berturut-turut adalah 93,33 persen, 86,67 persen dan 90,00 persen ditahun 2016 - 2018. 


\section{PT. Bank Rakyat Indonesia, Tbk}

Penilaian tingkat kesehatan Bank BRI dengan menggunakan metode RGEC yaitu dengan melihat aspek Risk Profile, Good Corporate Governance, Earnings dan Capital selama tahun 2014-2018 berada pada peringkat komposit 1 (PK-1) dengan kriteria sangat sehat. Dengan nilai berturut-turut adalah 96,67 persen, 93,33 persen, 96,67 persen, 93,33 persen, dan 90,00 persen.

\section{PT. Bank Tabungan Negara, Tbk}

Penilaian tingkat kesehatan Bank BTN dengan menggunakan metode RGEC yaitu dengan melihat aspek Risk Profile, Good Corporate Governance, Earnings dan Capital selama tahun 2014-2018 berturut-turut adalah 86,67 persen, 80,00 persen, 76,67 persen, 80,00 persen, dan 83,33 persen.

\section{4. $\quad$ PT. Bank Mandiri, Tbk}

Penilaian tingkat kesehatan Bank Mandiri dengan menggunakan metode RGEC yaitu dengan melihat aspek Risk Profile, Good Corporate Governance, Earnings dan Capital selama tahun 2014-2018 berada pada peringkat komposit 1 (PK-1) dengan kriteria sangat sehat. Dengan nilai berturut-turut adalah 93,33 persen pada tahun 2014 - 2015 dan 90,00 persen pada tahun 2016 - 2018.

\section{KESIMPULAN DAN SARAN}

Penilaian tingkat kesehatan bank dilihat dari faktor risk profile, good corporate governance, eraning, dan capital pada periode 2014 menunjukkan Bank BNI, Bank BRI, Bank BTN, dan Bank Mandiri mendapat peringkat komposit sangat sehat. Pada periode 2015menunjukkan Bank BNI, Bank BRI, dan Bank Mandiri mendapat peringkat komposit sangat sehat. Sedangkan Bank BTN mendapat peringkat komposit sehat. Pada periode 2016 menunjukkan Bank BNI, Bank BRI, dan Bank Mandiri mendapat peringkat komposit sangat sehat. Sedangkan Bank BTN mendapat peringkat komposit sehat. Pada periode 2017 menunjukkan Bank BNI, Bank BRI, dan Bank Mandiri mendapat peringkat komposit sangat sehat. Sedangkan Bank BTN mendapat peringkat komposit sehat. Pada periode 2018 menunjukkan Bank BNI, Bank BRI, dan Bank Mandiri mendapat peringkat komposit sangat sehat. Sedangkan Bank BTN mendapat peringkat komposit sehat.

\section{DAFTAR PUSTAKA}

Atyka, Nur. 2015. Penilaian Kesehatan Bank Dengan Metode RGEC Pada Bank Rakyat Indonesia (Persero) TBK Periode 2011 - 2013. Penelitian. Yogyakarta: Program Sarjana Universitas Negeri Yogyakarta. 
Bank Indonesia. 2013. Peraturan Bank Indonesia No. 15/ 12/ PBI/ 2013 Tentang Giro Wajib Minimum Bank Umum Dalam Rupiah Dan Valuta Asing Bagi Bank Umum Dan Konvensional. Jakarta: Bank Indonesia.

Bank Indonesia. 2013. Surat Edaran Bank Indonesia No. 15/15/ DPNP Perihal Pelaksanaan Good Corporate Governance bagi Bank Umum. Jakarta: Bank Indonesia.

Bank Indonesia. 2011. Peraturan Bank Indonesia No. 13/ 1/ PBI/ 2011 Tentang Penilaian Tingkat Kesehatan Bank Umum. Jakarta: Bank Indonesia.

Bank Indonesia. 2011. Surat Edaran Bank Indonesia Nomor. 13/ 24/ DPNP/ 2011 pada tanggal 25 Oktober 2011 tentang Matriks Perhitungan Analisis Komponen Faktor Analisis RGEC untuk Bank Umum. Jakarta: Bank Indonesia.

Bank Indonesia. 2008. Peraturan Bank Indonesia Nomor 10/15/PBI/2008 Tentang Kewajiban Penyediaan Modal Minimum Bank Umum. Jakarta: Bank Indonesia.

Bank Indonesia. 1998. Undang - Undang No. 10 Tahun 1998 Tentang Perbankan. Jakarta: Bank Indonesia.

Budisantoso, Totok dan Nuritomo. 2014. Bank dan Lembaga Keuangan Lainnya. Jakarta. Salemba Empat.

Budisantoso, Totok dan Triandaru Sigit. 2006. Bank dan Lembaga Keuangan Lain. Salemba Empat. Jakarta.

Bursa Efek Indonesia. 2012. Laporan Keuangan E Tahunan. (www.idx.co.id). Diakses pada hari senin, 06 November 2017 pukul 12.16 WIB.

Hasibunan, Malayu SP. 2011. Dasar - Dasar Perbankan. PT Bumi Aksara. Jakarta.

Iskandar, Syamsu. 2013. Bank Dan Lembaga Keuangan Lainnya. Jakarta. In Media.

Ikatan Akuntan Indonesia. 2000. Standar Akuntansi Keuangan Revisi Tahun 2000. Jakarta : Salemba empat.

Kasmir. 2014. Bank dan Lembaga Keuangan LainnyaEdisi Revisi. Jakarta. PT Raja Grafindo Persada.

Mahendra, Komang dan Luh Gede Sri. 2016. Analisis Tingkat Kesehatan Bank (Pendekatan RGEC) Pada PT. Bank Danamon Tbk. Jurnal Unud. Volume 5. Nomor 6. ISSN: $2302-8912$.

Nurul Badriyah, Abid Muhtarom. 2020. Configuration of Employment Training to Improving Work Competencies Toward Competitiveness. Jurnal Atlantis Press; Advances in Economics, Business and Management Research Volume 115. Proceedings of the 17 th International Symposium on Management (INSYMA 2020).

Otoritas Jasa Keuangan. 2016. Peraturan Otoritas Jasa Keuangan Nomor 4/ POJK. 03/ 2016 Tentang Penilaian Tingkat Kesehatan Bank Umum. Jakarta: Ketua Dewan Komisaris OJK.

Pramartha, Dewa Gede Derian Angga dan Ketut Mustanda. 2017. Analisis Penilaian Tingkat Kesehatan Bank Pada PT. Bank Central Asia. Tbk Berdasarkan Metode RGEC. Jurnal Unud. Volume 6. Nomor 1. ISSN: 2302 - 8912. 
Putri, Ratna Lutfiani. 2017. Analisis Tingkat Kesehatan Bank (Pendekatan RGEC) Pada Bank Rakyat Indonesia 2013 - 2015. Jurnal Ilmu dan Riset Akuntansi. Volume 6. Nomor 8. ISSN: 2460 - 0585.

Sugiyono. 2016. Metode Penelitian Kuatitatif, kualitatif dan RED. Bandung. Alfabeta.

Susanti, Sandhy Dharmapermata. 2015. Analisis Tingkat Kesehatan Bank Dengan Menggunakan Metode Risk - Based Bank Rating (RBBR). Penelitian. Yogyakarta: Fakultas Ekonomi Universitas Negeri Yogyakarta.

Sudarto, Suwarno. Dkk. 2013. Commercial Bank Management Manajemen Perbankan Dari Teori ke Praktik. Jakarta. PT Raja Grafindo Persada.

Taufik, Sholla. 2009. Kronologi Aliran Rp 6,7 Triliun ke Bank Century. Tempo.co. (Online). (https://nasional.tempo.co/read/1068079/sekjen-demokrat-nama-ahymenguat-di-bursa-pilpres). Diakses pada tanggal 08 Maret 2018.

Titin, Abdul Ghofur. 2020. The Impact of MultiChannel's Single Phase Queue and E-KTP Process Service on Community Satisfaction in Lamongan Regency. Jurnal Antlantis Press; Advances in Economics, Business and Management ResearchVolume 115. Proceedings of the 17 th International Symposium on Management (INSYMA 2020). 